\title{
Field-Relevant New Sources of Resistance to Anthracnose Caused by Colletotrichum truncatum in a Mungbean Mini-Core Collection
}

\author{
Abhay K. Pandey, ${ }^{1,2, \dagger}$ Ashwani K. Basandrai, ${ }^{3}$ Daisy Basandrai, ${ }^{4}$ Venkata Naresh Boddepalli, ${ }^{1}$ Abhishek Rathore, ${ }^{5}$ Gopikrishna \\ Adapala, ${ }^{5}$ and Ramakrishnan M. Nair ${ }^{1, \dagger}$ \\ ${ }^{1}$ World Vegetable Center, South Asia, ICRISAT Campus, Patancheru, Hyderabad-502324, TS, India \\ ${ }^{2}$ Tea Research Association, North Bengal Regional R \& D Center, Nagrakata-735225, West Bengal, India \\ ${ }^{3}$ Department of Plant Pathology, College of Agriculture, CSK Himachal Pradesh Agricultural University, Palampur-176062, Himachal \\ Pradesh, India \\ ${ }^{4}$ Department of Genetics and Plant Breeding, College of Agriculture, CSK Himachal Pradesh Agricultural University, Palampur-176062, \\ Himachal Pradesh, India \\ ${ }^{5}$ International Crop Research Institute for the Semi-Arid Tropics, Hyderabad-502324, TS, India
}

\begin{abstract}
Anthracnose is a prevalent disease of mungbean in Asian countries and Sub-Saharan Africa. It is caused by multiple Colletotrichum species. The high levels of anthracnose resistance in mungbean have not been studied in depth in India, but genetic resistance is desired. In this study, we identified the causal agent of mungbean anthracnose in two regions of India as Colletotrichum truncatum through morphological and molecular methods. A set of 296 mungbean mini-core accessions developed by WorldVeg was screened under a natural disease pressure from July to September (kharif season) in 2016, 2017, and 2018 in Hyderabad (a hot spot for anthracnose) to identify anthracnose resistance. Based on disease severity scores, 22 accessions were consistently anthracnose resistant under the categories of immune, highly resistant, and resistant with scores ranging from $\geq 1.0$ to $\leq 3.0$ during the period of study. Furthermore, based on the agronomic per-

Palampur (another hot spot for anthracnose) to determine the variation in anthracnose resistance. Out of the 74 accessions, two accessions were resistant in 2018; in 2019, one was immune, nine were highly resistant, and 15 were resistant. Combined analysis of variance of 65 accessions common in Hyderabad and Palampur revealed highly significant effects of environment, genotype (accessions), and genotype $\times$ environment interaction on the disease severity. The combined GGE biplot analysis of data across years and locations confirmed that the seven accessions MC-24, MC-51, MC-75, MC-127, MC-207, MC-208, and MC-292 were resistant during 2016 to 2018 in Hyderabad, and only in 2019 in Palampur, and the same accessions were moderately resistant in 2018 in Palampur. The seven resistant accessions identified from both test locations could be used as potential donors in the anthracnose resistance breeding program.
\end{abstract} formance, anthracnose resistance in Hyderabad, and other desirable traits, a subset of 74 mungbean accessions was selected from 296 mini-core accessions. These accessions were evaluated under natural disease pressure from July to September in 2018 and 2019 in
Keywords: Vigna radiata, Colletotrichum truncatum, host plant resistance, genotype $\times$ environment interaction, GGE biplot, molecular characterization
Food legumes are important sources of dietary protein and other essential nutrients (Udomkun et al. 2019). Mungbean (Vigna radiata [L.] R. Wilczek var. radiata), also known as the green gram, is the main crop in cereal-based farming systems in Asia, Sub-Saharan Africa, Australia, and South America (Mbeyagala et al. 2017; Nair et al. 2019; Noble et al. 2019). Worldwide, the total cultivated area and production are $\sim 7$ million ha and 5 million t, respectively (Nair et al. 2019). It is an ideal crop for smallholder farmers due to its low input requirement, nitrogen fixation capability, and short duration that makes it highly suited for crop rotation. The yield potential of

${ }^{\dagger}$ Corresponding authors: A. K. Pandey; abhaykumarpandey.ku@gmail.com, and R. M. Nair; ramakrishnan.nair@worldveg.org

Funding: The funding for this research work was given by core donors to the World Vegetable Center: Republic of China (Taiwan), United States Agency for International Development (USAID), UK aid, Australian Centre for International Agricultural Research (ACIAR) through an ACIAR Project on International Mungbean Improvement Network (CIM2014-079), Germany, Thailand, Philippines, Korea, and Japan.

*The $\boldsymbol{e}$-Xtra logo stands for "electronic extra" and indicates that two supplementary figures are published online.

The author(s) declare no conflict of interest.

Accepted for publication 16 February 2021.

Copyright $\odot 2021$ The Author(s). This is an open access article distributed under the CC BY-NC-ND 4.0 International license. mungbean ranges from 2.5 to 3.0 t/ha; however, the global average productivity of mungbean is $\sim 0.5 \mathrm{t} / \mathrm{ha}$. The rich protein content ( $\sim 25 \%)$ and higher content of essential amino acids make mungbean an ideal crop to defeat malnutrition, particularly for the vegetarian population of developing countries. South Asia contributes $90 \%$ of total mungbean production worldwide, and India is the largest producer in South Asia with production of about 1.5 to 2.0 million $t$ from about 3 to 4 million ha annually, with average productivity of $0.5 \mathrm{t} / \mathrm{ha}$ (Pratap et al. 2020). The production is hampered by several biotic and abiotic stresses, including anthracnose that is a prevalent fungal disease widely spread in Asian countries (Nair et al. 2019; Shukla et al. 2014) and Sub-Saharan Africa (Mbeyagala et al. 2017). Mungbean anthracnose is caused by multiple species of the fungus Colletotrichum. The pathogen is seed and soil-borne, ubiquitous in nature, but its severity depends on the weather conditions (Kulkarni 2009; Mandal et al. 2015). The disease causes yield and quality loss, and 30 to $70 \%$ yield loss has been estimated in India (Deeksha and Tripathi 2002; Shukla et al. 2014). The yield loss is proportional to the disease severity, and it differs depending on the host lines and environmental conditions. The infection of pods directly damages the seeds and reduces their germination capacity and may result in complete yield loss.

Mungbean growers in developing countries use carbendazim and mancozeb fungicides to manage the disease (Chaudhari and Goel 2016; Khan et al. 2005; Shukla et al. 2014). Both these fungicides are frequently used for control of Colletotrichum truncatum (Schw.) Andrus and Moore (syn. C. capsici Butler \& Bisby) causing anthracnose in other crops, such as soybean (Jagtap and Sontakke 2009), chili (Goswami et al. 2013), and urdbean (Saha and Mohanty 2017). 
However, the development of resistance to carbendazim and mancozeb fungicides has been seen in the population of $C$. truncatum (Poti et al. 2020; Torres-Calzada et al. 2015). In addition, the use of fungicides is not cost-effective and reliable to manage the disease, and the problem of water, soil, and environmental pollution discourages the application of fungicides. On the other hand, anthracnose-resistant varieties would be cost-effective, practically feasible, eco- and farmerfriendly, and a viable alternative to manage this disease.

Screening for anthracnose resistance using the detached leaf method in laboratory and glasshouse screening with artificial inoculation (Bigirimana and Höfte 2001; Miller-Butler et al. 2018) has been carried out; however, the results were not accurate and reproducible due to the short duration of host $\times$ pathogen interactions and controlled environments. Therefore, screening of germplasm in the field under natural disease pressure could be recommended, as it provides a longer period of host $\times$ pathogen $\times$ environment interactions and leads to more accurate and reproducible results (Kaur et al. 2011). However, multiple host ranges (Buchwaldt et al. 2013; Goswami et al. 2013; Rogério et al. 2019), and pathogenic and genetic variability (Sharma et al. 2005, 2011) in C. truncatum, makes screening crops for resistance complicated (Kaur et al. 2011). Hence, progress in the breeding for anthracnose-resistant cultivars in mungbean is limited.

Proper identification of anthracnose-causing species is also critical to identify potential resistant lines. Morphological and molecular methodologies are both used to identify different Colletotrichum species from several crops (Abang et al. 2002; Freeman et al. 2000), and significant work has been done on the molecular characterization of C. truncatum (Diao et al. 2014; He et al. 2016; Marak et al. 2019; Oo and Oh 2020). The pathogen's identification based on cultural and morphological characters is often inconclusive, and serological and biochemical methods are also commonly used to identify certain pathogen species. However, these methods are available only for a limited number of species (Rani et al. 2019). Presently, molecular techniques such as the sequencing of internal transcribed spacers (ITS) of 18S rRNA and housekeeping genes, use of species-specific primers, random amplification of polymorphic DNA (RAPD) analysis, and loop-mediated isothermal amplification (LAMP)-based detection are often used to identify Colletotrichum species (Damm et al. 2019; Rogério et al. 2019).

Genetic improvement of any crop requires accessibility to a good germplasm collection. However, evaluation of a large number of genotypes against a pathogen takes significant time and resources. A core collection of 1,486 mungbean accessions was developed at the World Vegetable Center, Taiwan, in 2015 (Schafleitner et al. 2015), and screening all accessions is not currently feasible. It has been proposed that screening $10 \%$ of a germplasm collection is sufficient to cover the most useful variation in a plant species (Frankel 1984; Upadhyaya et al. 2006). The objectives of the present study were: (i) to identify the fungal species causing mungbean anthracnose in India, and (ii) to identify resistance sources against anthracnose-causing species from the 296 mini-core collections.

\section{Materials and Methods}

Isolation of the pathogen. For characterization of the pathogen, in 2016, anthracnose symptomatic mungbean leaves were collected randomly in three replicates (each replicate contained a set of five leaf samples) from the research plots of Hyderabad. The symptomatic leaves were kept in presterilized polyethylene bags and brought to the lab for pathogen identification. The pathogen was isolated from symptomatic leaves on potato dextrose agar (PDA) (Himedia, India) medium using the standard mycological procedures (Sain and Pandey 2018). The culture of the pathogen was purified through a single spore isolation method and preserved at $4{ }^{\circ} \mathrm{C}$ on PDA slants for further studies.

Cultural and morphological analysis. The pathogen was identified based on cultural (colony color, characteristics of mycelia, growth pattern) and morphological (morphology of conidia and septation) characteristics (Marak et al. 2019). Twenty-five randomly chosen conidia were measured for length and width with an Olympus binocular microscope. Similarly, the pathogen causing anthracnose in mungbean leaf, stem, and pod was isolated and identified from each year's research plot of Hyderabad and Palampur, separately. The isolates were designated as $\mathrm{CtH} 2016, \mathrm{CtH} 2017$, and CtH2018 for Hyderabad, and CtP2018 and CtP2019 for Palampur.

Extraction of genomic DNA from the pathogen, ITS-rDNA amplification, and sequencing analyses. In 2018, the isolates of $\mathrm{CtH}$ and $\mathrm{CtP}$ isolated from Hyderabad and Palampur samples, respectively, were further identified by sequencing the ITS regions. The ITS regions (ITS1, 5.8S, and ITS2) of the nuclear rDNA operon of both isolates were amplified and sequenced, separately. The genomic DNA (gDNA) from each isolate was extracted using the CTAB method (Möller et al. 1992) and quantified with a NanoDrop1000 spectrophotometer (Thermo Scientific). The rDNA gene cluster was amplified by PCR using universal primer pairs ITS1/ITS4 following White et al. (1990). The amplified PCR products of each isolate were separated by electrophoresis on a $2 \%$ agarose gel, and the obtained bands were excised and purified (UniPro Gel extraction kit) for sequencing (Macrogen, Inc., Korea). BLASTn was used to match $C$. truncatum sequencing results of each isolate with known sequences of $C$. truncatum strains accessible at the public database GenBank.

Evaluation of mungbean mini-core accessions for anthracnose resistance in Hyderabad (south India). Seeds of 296 mungbean mini-core accessions, maintained by the World Vegetable Center, South Asia Hyderabad, India, were utilized in this study. These accessions were developed from a core collection of 1,481 mungbean accessions at the World Vegetable Center, Taiwan, in 2015, and have a diverse origin including Africa, Europe, Central America, North America, Oceania and the Pacific, South Asia, South America, Southeast Asia, and Southwest Asia (Schafleitner et al. 2015).

The 296 mungbean mini-core accessions were evaluated under natural disease pressure for anthracnose resistance from July to September (kharif season) at the World Vegetable Center, South Asia, Hyderabad $\left(17^{\circ} \mathrm{N}, 78^{\circ} \mathrm{E}\right.$, elevation $\left.550 \mathrm{~m}\right)$, India, in 2016, 2017, and 2018. The chosen location was known for high levels of anthracnose severity in South India in earlier cropping periods. In the field, in each year of the evaluation trial, the accessions were arranged in an alpha lattice design (also known as resolvable incomplete block design, Supplementary Fig. S1) with two replications. In total, 15 seeds were sown per accession in each replicate with the spacing of $60 \mathrm{~cm}$ (row to row) $\times 20 \mathrm{~cm}$ (plant to plant) in a plot of $1.5 \mathrm{~m} \times 0.6 \mathrm{~m}$ size with path length of $0.75 \mathrm{~m}$ covering $400 \mathrm{~m}^{2}$ total area.

Evaluation of selected mungbean mini-core accessions for anthracnose resistance in Palampur (North India). A subset of 74 accessions was selected from 296 mungbean mini-core accessions based on their anthracnose resistance and agronomic performance in Hyderabad. These selected accessions have also shown other disease resistance, such as dry root rot, Cercospora leaf spot, and powdery mildew in preliminary evaluation trials conducted in Myanmar, Pakistan, and India. Besides, these 74 accessions also contained few anthracnose-susceptible accessions identified in Hyderabad. These accessions were evaluated at the experimental farm of the Department of Plant Pathology, CSK Agricultural University, Palampur $\left(32^{\circ} \mathrm{N}\right.$ and $76^{\circ} \mathrm{E}$, elevation $\left.2,250 \mathrm{~m}\right)$, Himachal Pradesh, India, in 2018 and 2019, to determine the variation in anthracnose resistance at different locations. The chosen location was known for high levels of anthracnose severity in North India in earlier cropping periods. In the field, in each year of evaluation trial, the accessions were arranged in an alpha lattice design with three replications. In total, 15 seeds per accession were sown in each replicate with the spacing of $60 \mathrm{~cm}$ (row to row) $\times 20 \mathrm{~cm}$ (plant to plant) in a plot $1.5 \mathrm{~m} \times 0.6 \mathrm{~m}$ size with path length $0.50 \mathrm{~m}$ in $360 \mathrm{~m}^{2}$ total areas.

In each year of the evaluation trial at both the locations, a preemergence herbicide pendimethalin was applied in the soil at $3 \mathrm{ml} /$ liter per $20 \mathrm{~m}^{2}$ of field, 2 days prior to sowing. At 25 days after sowing, a manual hand-weeding was done for weed management. Also, to overcome other confounding effects by pests and diseases in research plots, appropriate management practices were carried out following the mungbean field manual of Mbeyagala et al. (2017). During the evaluation trials for anthracnose resistance at both locations, no other disease was noticed, except mungbean yellow mosaic disease (MYMD) in a few patches in Hyderabad. For the management of MYMD in Hyderabad and other soil-dwelling insect pests at 
both test locations each year, seeds were treated with Thiamethoxam at $4 \mathrm{~g} / \mathrm{kg}$ seeds prior to the sowing. In addition, for control of the vector (whitefly), 8 to 10 yellow sticky traps/acre were installed each year in the research plots at both locations.

Disease assessment. Depending on the disease severity, 45 or 60 days after sowing, the disease severity score of each accession was recorded on five randomly selected plants within a row using a 1-to9 point rating scale. The accessions with disease severity scores of ' 1 ' were considered immune (I: no infection). The accessions with disease severity scores $>1.0$ to $\leq 2.0$ were considered highly resistant (HR: 0.1 to $5 \%$ foliage affected), those with scores $>2.0$ to $\leq 3.0$ were considered resistant (R: 6 to $10 \%$ foliage affected), those with scores $>3.0$ to $\leq 4.0$ were considered moderately resistant (MR: 11 to $15 \%$ foliage affected), those with scores $>4.0$ to $\leq 5.0$ were considered moderately susceptible (MS: 16 to $20 \%$ foliage affected), those with scores $>5.0$ to $\leq 7.0$ were considered susceptible (S: 21 to $50 \%$ foliage affected), and those with scores $>7.0$ to $\leq 9.0$ were considered highly susceptible (HS: above $51 \%$ foliage affected).

Agronomic characteristics and weather data. The data for days to $50 \%$ flowering, days to maturity, and seed yield per plant of the mini-core accessions at both locations were collected. The weather data were obtained from ICRISAT (International Crops Research Institute for the Semi-Arid Tropics), Hyderabad and CSK, HPAU, Palampur. Weekly data for temperature, relative humidity, and rainfall (precipitation) were retrieved for each year during the experimental period. The average weekly values were calculated for temperature, relative humidity $(\mathrm{RH})$, and weekly sum for rainfall (precipitation).

Statistical analyses. The statistical analysis for the mungbean mini-core accessions included an ANOVA (analysis of variance) for each environment and a combined analysis across environments to test the significance. The replicate-wise values were used for statistical analysis. The disease severity score data were square-root transformed prior to analysis to make the residual normal. To test the significance of genotype $(\mathrm{G})$, environment $(\mathrm{E})$, and genotype $\times$ environment $(\mathrm{G} \times \mathrm{E})$ interactions, transformed data were used following the MIXED procedure of SAS 9.4 version (SAS Institute 2018) by considering replication, environment, and genotype (accession) as random effects. In the combined analysis, to make the error variance homogeneous, individual environment variances were estimated and modeled to error distribution, and from combined analysis, best linear unbiased predictors (BLUPs) were estimated for genotype, environment, and genotype $\times$ environment interaction. Additionally, Tukey's test was performed as posthoc analysis across years and locations to know which pair of accessions are significantly different, if genotype (accession) effect was found significant from ANOVA. A normality test was performed on residuals to test the assumptions of ANOVA and Shapiro-Wilk's test showed nonsignificant at $1 \%$ level of significance.

GGE biplot analysis. In the present study, 65 mungbean accessions common in Hyderabad and Palampur (HP) in all the five environments were used for GGE biplot analysis to verify the stability and to identify the ideal accessions across the G, E, and $\mathrm{G} \times \mathrm{E}$ (Yan et al. 2000) using the GENSTAT 20th edition for Windows (VSN International 2019). To show the patterns of $G \times E$ interaction, and to differentiate (a) performance of genotype and stability of genotype across all the test environments, (b) discriminating genotypes and environment effect, and (c) to recognize patterns whereby particular genotypes may be suggested for particular environments, the site regression model was used in the biplot analysis.

The GGE biplot was created by plotting the mean disease severity scores of $\mathrm{G}$ and $\mathrm{E}$ as first principal components (PC1) on the $\mathrm{X}$-axis against their respective disease severity scores for the second principal component (PC2) on the Y-axis, which was derived from the arcsine transformed values of environment-centered data (Yan and Kang 2002). Singular value decomposition (SVD) was achieved by providing a scaling factor $f$ to obtain alternative $\mathrm{G}$ and $\mathrm{E}$ scores. For assessment of ideal genotypes, the performance of both the mean disease severity scores and stability of genotypes across all the test environments were considered and shown through the average environment coordination (AEC) view of the biplot, which facilitated the comparisons of genotypes based on mean anthracnose severity scores and stability of genotypes across environments within a mega environment (Yan and Kang 2002). The estimation of AEC was carried out by calculating the mean of PC1 and PC2 scores for test environments. In the biplot, the mean performance of a genotype was determined by a performance line passing through the origin of the biplot. A genotype closer to the performance line in the biplot is considered more stable than that of a distance farther from the biplot origin on either side of the stability line representing relatively lower stability.

In addition, the relationship among test environments over the years was examined through the constructed biplot. The estimate of the test environments was shown by discriminating ability that was determined by the longest length of the environment vector, and representativeness of the environment that was shown by an acute angle with AEC/AE axis of the GGE biplot (Yang et al. 2009). The environments with longer vectors had more discrimination power and competence for genetic differentiation of the genotypes/accessions, and the locations with shorter vectors had the least discrimination. A model test environment is one presenting a high projection value onto the AEC abscissa that shows principal effects of genotypes more discriminative, and onto the AEC coordinate a small absolute projection value that shows all the test environments more representative.

\section{Results}

Field observations and disease symptoms. During the study, anthracnose symptoms on foliage appeared as brick red to dark brown lesions (Fig. 1a). Lesions were usually sunken or elongated or circular on the stem, leaf petioles, veins, and pods (Fig. 1b and c). In severe cases (leaves with dark brown necrotic lesions), the lesion eventually developed on a large portion of a single leaf or pods, causing it to fall from the mungbean plants.

Cultural and morphological characteristics of the pathogen. The investigation of each year's anthracnose symptomatic leaf/stem/ pod samples from Hyderabad and Palampur research plots revealed that the pathogen was $C$. truncatum. In total, five isolates of $C$. truncatum were characterized through visual and morphological methods, and one isolate from each test location isolated in 2018 was selected for DNA extraction, PCR amplification, and sequencing. On PDA plates, isolates of $\mathrm{CtH}$ isolated in 2016 and 2018 from Hyderabad research plots showed dense mycelial growth with dark olive color and abundant acervuli (Fig. 1d), whereas the isolates of $\mathrm{CtH}$ isolated in 2017 showed slow mycelial growth and sparse acervuli (Table 1). The isolates of CtP isolated from Palampur research plots in 2018 showed light olive colonies, yellowish brown with rings, thin mycelial growth with sparse acervuli (Fig. 1e), while that isolated in 2019 showed dense mycelial growth on PDA with abundant acervuli (Table 1). Based on the ITS sequences analyzed by BLASTn, the results revealed that both the isolates, $\mathrm{CtP}$ and $\mathrm{CtH}$, belonged to the species $C$. truncatum and shared 99 and $99.9 \%$ similarity with the ITS sequences of $C$. truncatum from the other hosts available in GenBank (NCBI). The sequences of isolates $\mathrm{CtH}$ and $\mathrm{CtP}$ were submitted to GenBank under the accession numbers MT394500 and MT394499, respectively.

Under the microscopic examination, all the isolates of $\mathrm{CtH}$ and $\mathrm{CtP}$ of $C$. truncatum showed slight differences in the conidial dimensions (Fig. 1f and g), and ascospore formation was absent in the analyzed samples. The morphological analysis of all the isolates of C. truncatum from Hyderabad and Palampur revealed that they were identical to each other. Overall, the conidia of all the isolates were curved, boat-shaped, smooth, hyaline, tapering at both ends, and aseptate. The conidial size such as length $\times$ width of $\mathrm{CtH}$ and $\mathrm{CtP}$ isolates were varied depending upon the isolates (Table 1). In addition, CtP isolates showed the presence of oil droplets in the conidial cytoplasm.

Evaluation of mungbean mini-core accessions for anthracnose resistance in Hyderabad. Based on the mean disease severity scores, in 2016 in Hyderabad, out of the 296 accessions, there were $13 \mathrm{I}, 70 \mathrm{HR}, 83 \mathrm{R}, 71 \mathrm{MR}, 11 \mathrm{MS}, 34 \mathrm{~S}$, and $14 \mathrm{HS}$ accessions. The disease pressure increased during the cropping seasons 2017 and 2018 (Fig. 2). In 2017, none of the accessions were disease-free or 
showed an immune reaction, and based on the mean disease severity scores, there were $8 \mathrm{HR}, 63 \mathrm{R}, 79 \mathrm{MR}, 83 \mathrm{MS}, 60 \mathrm{~S}$, and $3 \mathrm{HS}$ accessions, whereas in 2018, it was $1 \mathrm{I}, 12 \mathrm{HR}, 67 \mathrm{R}, 71 \mathrm{MR}, 75$ MS, $60 \mathrm{~S}$, and $10 \mathrm{HS}$. About $56.08 \%$ of all accessions had mean disease severity scores $\geq 1.0$ to $\leq 3.0$ in 2016 ; however, the percentage of such accessions decreased in 2017 (23.9\%) and 2018 (27.02\%), whereas the majority of the accessions had anthracnose severity levels between 3.1 and 9.0 (Fig. 2).

The accessions MC-142 (VI002894B-BR), MC-223 (VI003907AG), MC-228 (VI003942AG), MC-231 (VI003948B-BR), MC-251, MC-254 (VI004307AG), MC-257 (VI004351AG), MC-258, MC-260 (VI004480AG), and MC-263 (VI004691AG) had severity scores ranging from 5.1 to 9.0 at Hyderabad in all the three years' evaluation trials. The disease severity means for each of the resistant categories in each year's trial were found to be significantly different $(P<0.0001)$ from the susceptible categories in ANOVA analysis. A posthoc Tukey's test showed that the means of disease severity among the accessions differed significantly from each other at $P<0.05$ in 2017 and 2018 evaluation trials. However, the means did not differ significantly from each other in the evaluation trial of 2016. The data recorded from the research plots revealed that out of the 296 mini-core accessions, 22 accessions were consistently anthracnose resistant in each year of evaluation trials (Table 2 ). The disease reaction of susceptible and resistant mini-core accessions at Hyderabad is demonstrated in Figure 2S.

Evaluation of selected mungbean mini-core accessions against anthracnose in Palampur. In 2018, out of the 74 accessions, two (MC-36 and MC-236) showed R reactions with mean disease severity scores of 3.0 and 2.6, respectively. Among the other accessions, 8 were MR, 19 were MS, and 45 were S (Table 2). In 2019, data were recorded for 65 accessions only (as nine accessions were not germinated/survived due to heavy rains). The accession MC-127 was disease-free, whereas nine accessions were HR. In 55 remaining accessions, based on their scores, 15 were $\mathrm{R}$, 10 were MR, 7 were MS, 8 were S, and 15 were HS (Table 2). At Palampur, $2.7 \%$ and $35.4 \%$ of all the accessions had mean disease severity scores $\geq 1.0$ to $\leq 3.0$ during cropping seasons 2018 and 2019, respectively, whereas the majority of the accessions had anthracnose severity levels between 3.1 and 9.0 (Table 2). Within respective years at Palampur, disease severity means for each of the resistant categories differed significantly $(P<0.0001)$ from the susceptible categories in ANOVA analysis. A posthoc Tukey's test showed that the disease severity means differed significantly from each other at $P<0.05$ in

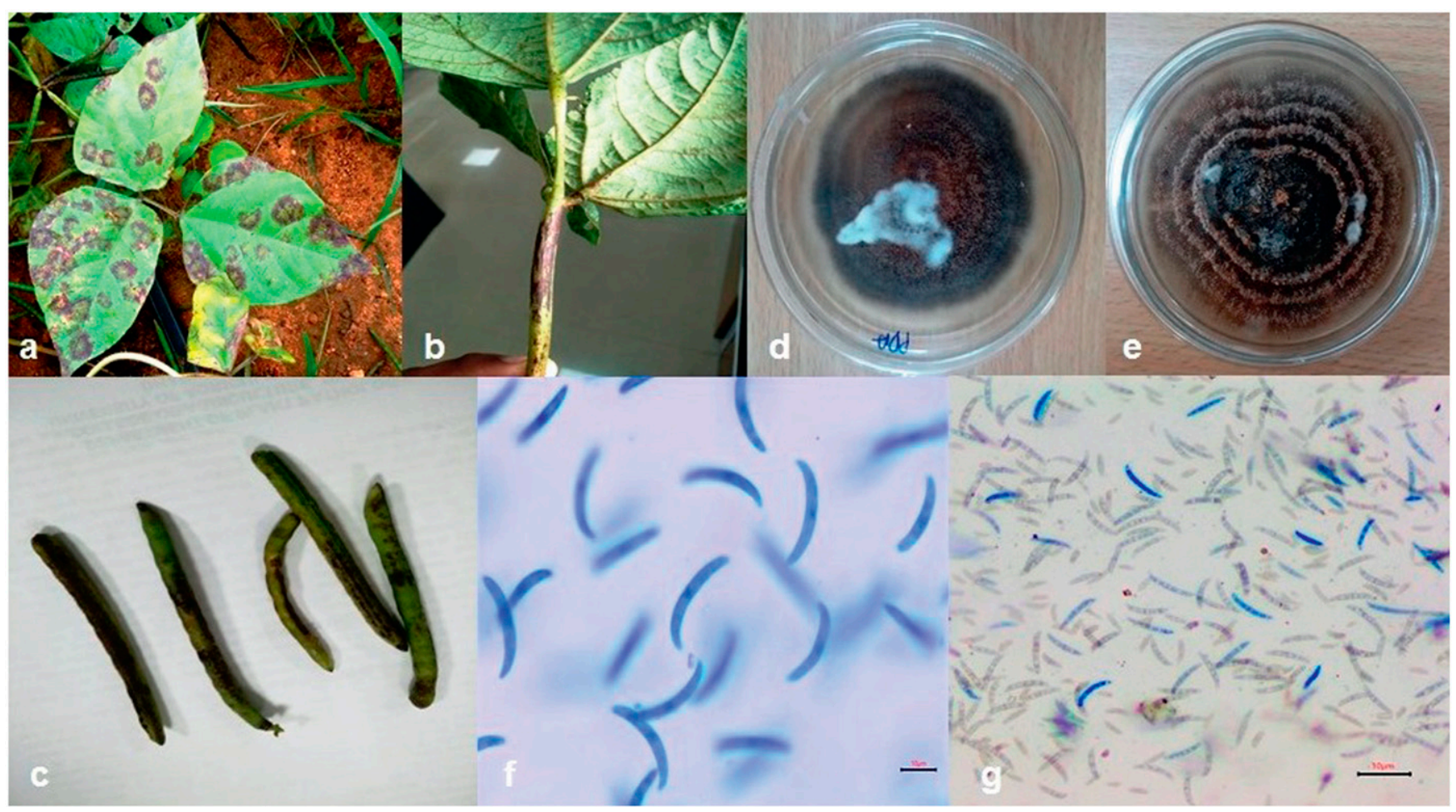

Fig. 1. Disease symptoms (a, on leaves; $\mathbf{b}$, on stem; $\mathbf{c}$, on pods), cultural and morphological characteristics of Colletotrichum truncatum causing anthracnose in mungbean in Hyderabad (CtH) (d, colony on the agar plate; $\mathbf{f}$, conidia) and Palampur (CtP) (e, colony on the agar plate; $\mathbf{g}$, conidia), India.

Table 1. Cultural and morphological characteristics of Colletotrichum truncatum isolates from Hyderabad and Palampur, India

\begin{tabular}{|c|c|c|c|c|c|c|}
\hline \multirow[b]{2}{*}{ Location } & \multirow{2}{*}{$\begin{array}{l}\text { Isolates of } \\
\text { C. truncatum }\end{array}$} & \multirow[b]{2}{*}{ Colony color/growth pattern ${ }^{y}$} & \multirow[b]{2}{*}{ Conidial shape } & \multicolumn{3}{|c|}{ Conidial length $\times$ width $(\mu \mathrm{m})$} \\
\hline & & & & Mean & Range & $\mathbf{S D}^{\mathbf{z}}$ \\
\hline \multirow[t]{3}{*}{ Hyderabad } & $\mathrm{CtH} 2016$ & Dark olive/+++ & $\begin{array}{l}\text { Curved, both apices } \\
\text { tapering, aseptate }\end{array}$ & $21.8 \times 5.6$ & $18.5-24.0 \times 5.0-7.5$ & $2.5 \times 1.1$ \\
\hline & $\mathrm{CtH} 2017$ & Dark olive/++ & $\begin{array}{l}\text { Curved, both apices } \\
\text { tapering, aseptate }\end{array}$ & $12.6 \times 3.5$ & $10.5-15.5 \times 3.0-4.5$ & $1.3 \times 0.4$ \\
\hline & $\mathrm{CtH} 2018$ & Dark olive/+++ & $\begin{array}{l}\text { Curved, both apices } \\
\text { tapering, aseptate }\end{array}$ & $24.3 \times 6.2$ & $22.0-28.0 \times 5.2-7.3$ & $1.5 \times 0.7$ \\
\hline \multirow[t]{2}{*}{ Palampur } & CtP2018 & $\begin{array}{l}\text { Light olive, yellowish brown } \\
\text { with ring/++ }\end{array}$ & $\begin{array}{l}\text { Curved, both apices } \\
\text { tapering, aseptate }\end{array}$ & $15.1 \times 3.3$ & $12.6-20.5 \times 2.5-3.8$ & $2.0 \times 0.5$ \\
\hline & CtP2019 & $\begin{array}{l}\text { Light olive, yellowish brown } \\
\text { with ring/+++ }\end{array}$ & $\begin{array}{l}\text { Curved, both apices } \\
\text { tapering, aseptate }\end{array}$ & $26.0 \times 6.9$ & $20.5-28.0 \times 5.8-7.5$ & $1.9 \times 0.5$ \\
\hline
\end{tabular}

\footnotetext{
y++: dense mycelial growth on PDA with abundant acervuli, ++: slow mycelia growth on PDA with sparse acervuli.
}

${ }^{\mathrm{z}} \mathrm{SD}$ : Standard deviation. 
2018; however, the means did not differ significantly from each other in the evaluation trial of 2019.

Overall, the accessions MC-24, MC-51, MC-75, MC-127, MC-207, MC-208, and MC-292 were anthracnose resistant under the categories of I, HR, and R at Hyderabad in all three years of evaluation trials, and in 2019 at Palampur. The accession MC-236, R at Palampur in 2018 and 2019, was also R at Hyderabad in 2016 and 2017, while it was MR in 2018 (Table 2).

Agronomic characteristics The mean values of the data recorded on days to $50 \%$ flowering, days to maturity, and yield per plant in selected mini-core accessions common in all environments are summarized in Table 2. Among the selected accessions, MC-72 was the earliest to flower (34 days), whereas MC-50 was the latest to flower (45 days), and the remaining accessions had an intermediate number of days to flowering (Table 2). The selected accessions were matured within the range of 62 to 79 days (Table 2), out of which accessions MC-194 and MC-292 were late maturing (>75 days), and the remaining accessions showed medium maturity groups (61 to 75 days). In total, 24 mini-core accessions recorded a higher seed yield of $>10$ g per plant compared with the trial mean among the selected accessions; however, there was no significant difference $(P<0.6892)$ between the accessions for seed yield per plant. Among the seven resistant accessions that showed consistent resistance and lower disease severity scores across years and locations, accession MC-207 was the earliest to flower, and MC-208 was early maturing, but the highest seed yield (19.56 g per plant) was recorded in the anthracnose-resistant accession MC-207 (Table 2).

Stability of genotypes and environments A set of 65 accessions common in all five environments, i.e., during cropping seasons 2016, 2017, and 2018 in Hyderabad and 2018 and 2019 in Palampur, were subjected to combined GGE analysis. The biplot analysis of 65 mungbean mini-core accessions explained $73.37 \%$ of the total variation, where first (PC1) and second (PC2) principal components accounted for 57.76 and $15.61 \%$ of variations, respectively (Fig. 3). On the biplot (Fig. 3), the octagon's vertices indicate the genotypes (accessions) that contributed the most to the interaction, i.e., those that showed the highest or the lowest anthracnose disease severity scores. In the figure, the arrowed line connecting the origin and environmental average (average of $\mathrm{PC} 1$ and $\mathrm{PC} 2$ coordinates across environments) shows the average environment coordination axis (AECa), the suitable tool to compare genotypes by their average performance and stability. The ideal genotype would be the one with the lowest disease severity score (a higher negative projection on AECa) and the highest stability (a projection close to zero on AECa) (Yan et al. 2000).

In the biplot, mini-core accessions placed at the right side of the Y-axis showed susceptibility to anthracnose irrespective of environments, while those accessions located at the left side were resistant to anthracnose across the test environments. The accessions MC-24, MC-51, MC-75, MC-127, MC-207, MC-208, and MC-292 had the lowest levels of anthracnose severity across years and locations. Hence, these accessions were located farthest from the origin point on the left side, compared with other accessions, indicating their anthracnose resistance and high levels of stability (Fig. 3). The accessions MC-40, MC-57, MC-107, MC-175, MC-258, and MC-251 were consistently more susceptible to anthracnose by showing susceptibility in the field, and thus were located farthest on the right side of the origin of the biplot and had high positive PC1 values. The accessions that were moderately stable to the test environments to anthracnose disease severity scores, e.g., MC-83, MC-92, MC-131, MC-146, MC-198, and MC-271, were placed on the right side of the point of origin (Fig. 3).

In the present study, all the test environments were discriminative for genotypes/accessions. In the biplot, this can be seen by the position of environment-year combinations that are away from the biplot origin. However, environments differed in their discriminativeness as represented by their different vector length. For example, the 2018 environment of Hyderabad (Hyd_2018) with longer vector length was highly discriminative of genotypes than the environments in 2017 (Hyd_2017) and 2016 (Hyd_2016). The biplot analysis also showed that the test environments that form the smallest angle with AECa line with near 0 projection value were the most representative

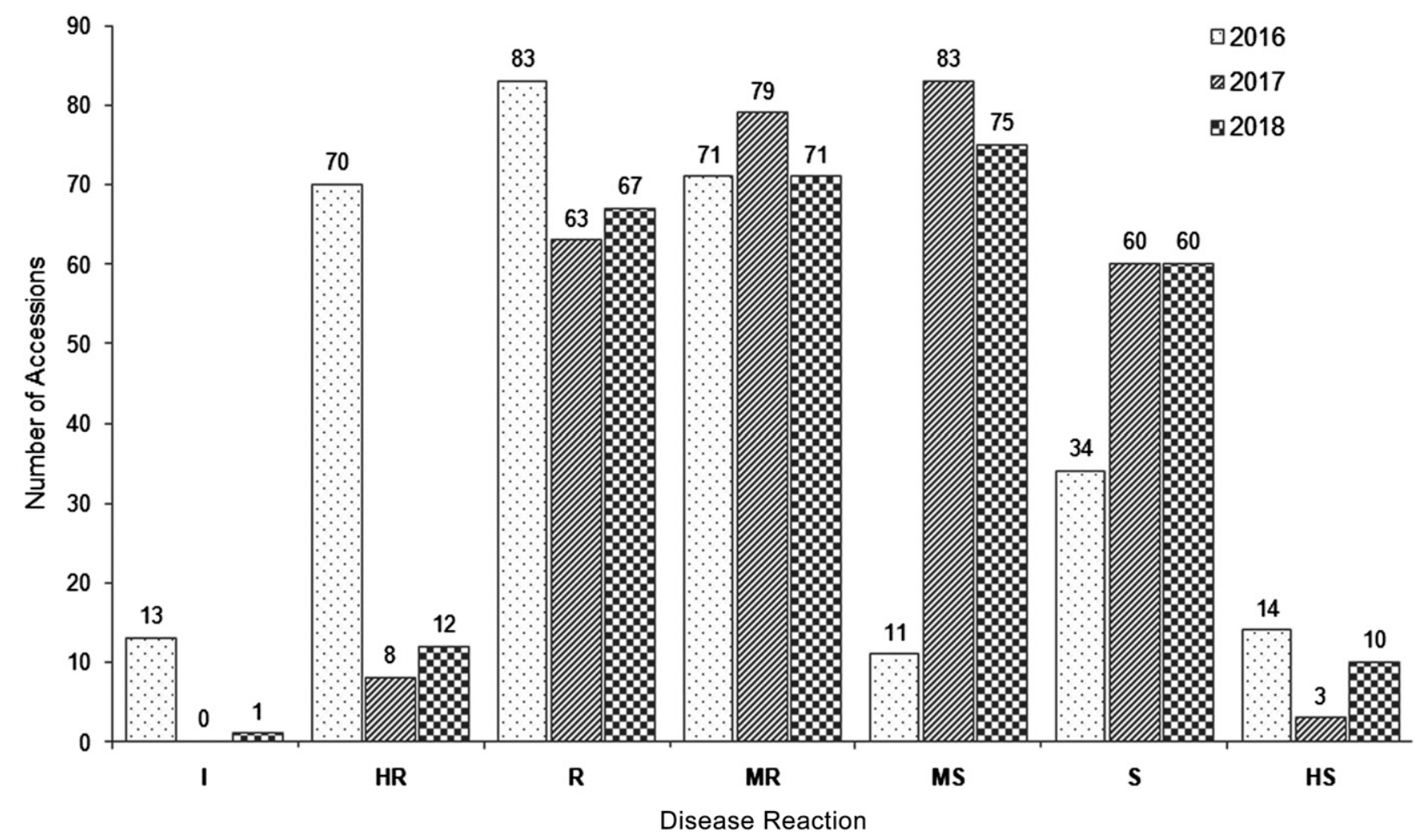

Fig. 2. Summary of disease reaction of 296 mungbean mini-core accessions to anthracnose in Hyderabad, India in 2016, 2017, and 2018. I, immune; HR, highly resistant; R, resistant; MR, moderately resistant; MS, moderately susceptible; S, susceptible; HS, highly susceptible. The disease was scored on a 1-to-9 point rating scale, where $1=\mathrm{I}$ and $9=\mathrm{HS}, P<0.0001$. 
Table 2. Disease severity scores on selected accessions from a multiyear and multilocation evaluation of a mungbean mini-core (MC) collection for anthracnose resistance in India and their agronomic characteristics

\begin{tabular}{|c|c|c|c|c|c|c|c|c|c|c|}
\hline \multirow{3}{*}{$\begin{array}{l}\text { MC } \\
\text { no. }\end{array}$} & \multirow{3}{*}{$\begin{array}{c}\text { Accession } \\
\text { name }\end{array}$} & \multirow[b]{3}{*}{ Origin } & \multicolumn{5}{|c|}{ Mean disease severity scores ${ }^{w}$} & \multicolumn{3}{|c|}{ Agronomic characteristics } \\
\hline & & & \multicolumn{3}{|c|}{ Hyderabad } & \multicolumn{2}{|c|}{ Palampur } & \multirow{2}{*}{$\begin{array}{c}\text { Days to } 50 \% \\
\text { flowering }\end{array}$} & \multirow{2}{*}{$\begin{array}{c}\text { Days to } \\
\text { maturity }^{\mathbf{y}, \mathbf{z}}\end{array}$} & \multirow{2}{*}{$\begin{array}{l}\text { Yield per } \\
\text { plant }(g)^{y}\end{array}$} \\
\hline & & & $2016^{x}$ & $2017^{x}$ & $2018^{x}$ & $2018^{x}$ & $2019^{x}$ & & & \\
\hline 1 & VI000020AY & Thailand & $1.0^{\mathrm{b}}$ & $1.4^{\mathrm{ef}}$ & $3.0^{\text {abcdefghijklmno }}$ & $4.3^{\text {abcd }}$ & $8.1^{\mathrm{ab}}$ & 39 & 64 & 7.9 \\
\hline 8 & VI000203B-BR & Afghanistan & $2.3^{\mathrm{ab}}$ & $3.3^{\text {abcdef }}$ & $7.5^{\text {abcdef }}$ & $5.9^{\mathrm{abcd}}$ & $3.0^{\mathrm{ab}}$ & 42 & 74 & 7.4 \\
\hline 9 & VI000212A-BLM & USA & $7.3^{\mathrm{ab}}$ & $8.5^{\mathrm{a}}$ & $2.6^{\text {bcdefghijklmnop }}$ & $4.0^{\mathrm{d}}$ & $\$$ & 40 & 71 & 5.8 \\
\hline 15 & VI000319AG & Pakistan & $1.5^{\mathrm{ab}}$ & $2.9^{\text {bcdef }}$ & $3.2^{\text {bcdefghijklmnop }}$ & $5.5^{\text {abcd }}$ & $3.0^{\mathrm{ab}}$ & 35 & 65 & 7.5 \\
\hline 16 & VI000380AG & Philippines & $2.0^{\mathrm{ab}}$ & $2.1^{\text {bcdef }}$ & $3.0^{\text {bcdefghijklmnop }}$ & $5.7^{\text {abcd }}$ & $\$$ & 37 & 66 & 10.1 \\
\hline 18 & VI000470AG & Pakistan & $2.2^{\mathrm{ab}}$ & $2.9^{\text {bcdef }}$ & $2.2^{\text {ghijklmnop }}$ & $6.0^{\mathrm{abc}}$ & $8.5^{\mathrm{a}}$ & 36 & 63 & 13.0 \\
\hline 20 & VI000537BG & India & $1.8^{\mathrm{ab}}$ & $2.1^{\text {bcdef }}$ & $3.6^{\text {abcdefghijklmno }}$ & $*$ & $*$ & 42 & 65 & 9.7 \\
\hline 24 & VI000559AG & India & $2.5^{\mathrm{ab}}$ & $2.5^{\text {bcdef }}$ & $2.5^{\text {efghijklmnop }}$ & $5.0^{\mathrm{abcd}}$ & $2.5^{\mathrm{ab}}$ & 39 & 69 & 7.0 \\
\hline 26 & VI000589B-BR & India & $3.5^{\mathrm{ab}}$ & $2.0^{\text {cdef }}$ & $4.3^{\text {abcdefghijklmno }}$ & $6.0^{\mathrm{abc}}$ & $\$$ & 40 & 72 & 6.2 \\
\hline 32 & VI000732AG & India & $1.9^{\mathrm{ab}}$ & $4.3^{\text {abcdef }}$ & $3.0^{\text {bcdefghijklmnop }}$ & $3.1^{\mathrm{cd}}$ & $4.9^{\mathrm{ab}}$ & 38 & 69 & 7.3 \\
\hline 36 & VI000764AG & India & $1.5^{\mathrm{ab}}$ & $2.3^{\text {bcdef }}$ & $2.9^{\text {bcdefghijklmnop }}$ & $3.0^{\mathrm{abcd}}$ & $\$$ & 38 & 66 & 9.1 \\
\hline 37 & VI000766BG & India & $2.4^{\mathrm{ab}}$ & $4.6^{\text {abcdef }}$ & $4.5^{\text {abcdefghijklmno }}$ & $5.9^{\mathrm{abc}}$ & $\$$ & 36 & 67 & 9.4 \\
\hline 38 & VI000805BG & India & $8.5^{\mathrm{ab}}$ & $5.1^{\text {abcdef }}$ & $4.9^{\text {abcdefghijklmno }}$ & $4.3^{\mathrm{abcd}}$ & $6.3^{\mathrm{ab}}$ & 35 & 64 & 10.0 \\
\hline 39 & VI000815BG & India & $1.4^{\mathrm{ab}}$ & $4.2^{\text {abcdef }}$ & $6.8^{\text {abcdefghijk }}$ & $5.9^{\text {abcd }}$ & $3.4^{\mathrm{ab}}$ & 37 & 65 & 12.8 \\
\hline 40 & VI000818BG & India & $1.5^{\mathrm{ab}}$ & $6.9^{\text {abcdef }}$ & $7.9^{\mathrm{a}}$ & $6.6^{\mathrm{a}}$ & $8.2^{\mathrm{a}}$ & 35 & 63 & 8.6 \\
\hline 41 & VI000852AG & India & $2.2^{\mathrm{ab}}$ & $3.1^{\text {abcdef }}$ & $3.6^{\text {abcdefghijklmno }}$ & $5.0^{\text {abcd }}$ & $\$$ & 37 & 64 & 11.1 \\
\hline 45 & VI000981BG & Philippines & $1.4^{\mathrm{ab}}$ & $2.4^{\text {bcdef }}$ & $5.7^{\text {abcdefghijklmn }}$ & $5.0^{\text {abcd }}$ & $4.1^{\mathrm{ab}}$ & 36 & 63 & 10.1 \\
\hline 50 & VI001126BG & Australia & $1.9^{\mathrm{ab}}$ & $5.2^{\text {abcdef }}$ & $2.5^{\text {cdefghijklmnop }}$ & $5.7^{\mathrm{abcd}}$ & $1.1^{\mathrm{b}}$ & 45 & 68 & 11.2 \\
\hline 51 & VI001162AG & Australia & $1.9^{\mathrm{ab}}$ & $3.0^{\text {abcdef }}$ & $2.6^{\text {bcdefghijklmnop }}$ & $4.3^{\mathrm{abcd}}$ & $2.9^{\mathrm{ab}}$ & 41 & 73 & 5.0 \\
\hline 53 & VI001211AG & Philippines & $2.5^{\mathrm{ab}}$ & $2.5^{\text {bcdef }}$ & $3.6^{\text {abcdefghijklmno }}$ & $4.9^{\mathrm{abcd}}$ & $8.2^{\mathrm{a}}$ & 40 & 71 & 10.2 \\
\hline 54 & VI001221AG & Philippines & $6.3^{\mathrm{ab}}$ & $2.7^{\text {bcdef }}$ & $3.1^{\text {bcdefghijklmnop }}$ & $5.6^{\mathrm{abcd}}$ & $8.2^{\mathrm{a}}$ & 37 & 65 & 8.5 \\
\hline 55 & VI001244AG & Philippines & $1.8^{\mathrm{ab}}$ & $3.7^{\text {abcdef }}$ & $5.5^{\text {abcdefghijklmn }}$ & $6.5^{\mathrm{ab}}$ & $7.4^{\mathrm{ab}}$ & 37 & 66 & 8.8 \\
\hline 56 & VI001268BG & India & $2.8^{\mathrm{ab}}$ & $3.1^{\text {abcdef }}$ & $3.8^{\text {abcdefghijklmno }}$ & $6.6^{\mathrm{a}}$ & $\$$ & 37 & 69 & 9.5 \\
\hline 57 & VI001282AG & India & $3.7^{\mathrm{ab}}$ & $6.6^{\text {abcdef }}$ & $3.0^{\text {bcdefghijklmnop }}$ & $6.0^{\mathrm{abc}}$ & $8.1^{\mathrm{ab}}$ & 36 & 66 & 10.2 \\
\hline 58 & VI001284AG & India & $5.6^{\mathrm{ab}}$ & $4.9^{\text {abcdef }}$ & $3.5^{\text {abcdefghijklmno }}$ & $5.9^{\text {abcd }}$ & $6.9^{\mathrm{ab}}$ & 37 & 64 & 8.5 \\
\hline 61 & VI001400AG & India & $1.1^{\mathrm{b}}$ & $2.2^{\text {bcdef }}$ & $3.5^{\text {abcdefghijklmno }}$ & $4.0^{\mathrm{abcd}}$ & $2.3^{\mathrm{ab}}$ & 43 & 70 & 9.7 \\
\hline 62 & VI001403BR & India & $3.0^{\mathrm{ab}}$ & $6.2^{\text {abcdef }}$ & $3.9^{\text {abcdefghijklmno }}$ & $5.9^{\text {abcd }}$ & $5.5^{\mathrm{ab}}$ & 42 & 71 & 7.6 \\
\hline 65 & VI001411AG & India & $3.6^{\mathrm{ab}}$ & $2.1^{\text {bcdef }}$ & $3.9^{\text {abcdefghijklmno }}$ & $3.9^{\text {abcd }}$ & $2.6^{\mathrm{ab}}$ & 41 & 68 & 8.5 \\
\hline 66 & VI001412AG & India & $1.4^{\mathrm{ab}}$ & $4.6^{\text {abcdef }}$ & $7.0^{\text {abcdefghi }}$ & $5.9^{\text {abcd }}$ & $2.9^{\mathrm{ab}}$ & 41 & 66 & 11.3 \\
\hline 67 & VI001419BG & India & $2.6^{\mathrm{ab}}$ & $2.4^{\text {bcdef }}$ & $5.2^{\text {abcdefghijklmno }}$ & $4.7^{\mathrm{abcd}}$ & $1.9^{\mathrm{ab}}$ & 42 & 74 & 7.4 \\
\hline 71 & VI001482BG & India & $2.0^{\mathrm{ab}}$ & $5.8^{\text {abcdef }}$ & $4.3^{\text {abcdefghijklmno }}$ & $5.2^{\mathrm{abcd}}$ & $3.7^{\mathrm{ab}}$ & 38 & 72 & 10.6 \\
\hline 72 & VI001490AG & Iran & $3.2^{\mathrm{ab}}$ & $3.8^{\text {abcdef }}$ & $4.3^{\text {abcdefghijklmno }}$ & $5.6^{\mathrm{abcd}}$ & $1.9^{\mathrm{ab}}$ & 34 & 63 & 9.4 \\
\hline 73 & VI001509AG & Pakistan & $3.5^{\mathrm{ab}}$ & $4.9^{\text {abcdef }}$ & $2.9^{\text {bcdefghijklmnop }}$ & $6.2^{\mathrm{ab}}$ & $3.4^{\mathrm{ab}}$ & 37 & 66 & 6.6 \\
\hline 74 & VI001514AG & India & $3.7^{\mathrm{ab}}$ & $3.0^{\text {abcdef }}$ & $2.9^{\text {bcdefghijklmnop }}$ & $5.0^{\text {abcd }}$ & $2.9^{\mathrm{ab}}$ & 40 & 72 & 6.7 \\
\hline 75 & VI001520A-BLM & India & $1.3^{\mathrm{ab}}$ & $1.7^{\mathrm{def}}$ & $1.9^{1 \mathrm{mnop}}$ & $5.7^{\text {abcd }}$ & $1.8^{\mathrm{ab}}$ & 39 & 73 & 9.4 \\
\hline 77 & VI001535BG & India & $1.9^{\mathrm{ab}}$ & $5.1^{\text {abcdef }}$ & $4.2^{\text {abcdefghijklmno }}$ & $3.7^{\mathrm{bcd}}$ & $3.9^{\mathrm{ab}}$ & 38 & 64 & 8.8 \\
\hline 79 & VI001548AG & India & $2.8^{\mathrm{ab}}$ & $2.5^{\text {bcdef }}$ & $2.5^{\text {efghijklmnop }}$ & $6.3^{\mathrm{ab}}$ & $4.3^{\mathrm{ab}}$ & 42 & 66 & 8.9 \\
\hline 83 & VI001576BG & India & $2.3^{\mathrm{ab}}$ & $2.7^{\text {bcdef }}$ & $4.5^{\text {abcdefghijklmno }}$ & $6.7^{\mathrm{a}}$ & $5.9^{\mathrm{ab}}$ & 37 & 68 & 8.9 \\
\hline 88 & VI001651BG & India & $2.5^{\mathrm{ab}}$ & $3.0^{\text {abcdef }}$ & $2.0^{\operatorname{lmnop}}$ & $*$ & $*$ & 39 & 66 & 10.8 \\
\hline 89 & VI001652BG & India & $2.4^{\mathrm{ab}}$ & $2.8^{\text {bcdef }}$ & $3.0^{\text {bcdefghijklmnop }}$ & $*$ & $*$ & 41 & 66 & 10.0 \\
\hline 92 & VI001692AG & India & $5.6^{\mathrm{ab}}$ & $4.6^{\text {abcdef }}$ & $4.8^{\text {abcdefghijklmno }}$ & $6.0^{\mathrm{abc}}$ & $4.5^{\mathrm{ab}}$ & 37 & 64 & 11.0 \\
\hline 94 & VI001728AG & India & $1.3^{\mathrm{ab}}$ & $3.0^{\text {bcdef }}$ & $2.6^{\text {bcdefghijklmnop }}$ & $*$ & $*$ & 39 & 72 & 9.8 \\
\hline 102 & VI001859BG & Thailand & $5.8^{\mathrm{ab}}$ & $3.7^{\text {abcdef }}$ & $3.8^{\text {abcdefghijklmno }}$ & $6.4^{\mathrm{ab}}$ & $9.0^{\mathrm{a}}$ & 41 & 70 & 8.4 \\
\hline 106 & VI002012BG & India & $1.3^{\mathrm{ab}}$ & $5.3^{\text {abcdef }}$ & $3.9^{\text {abcdefghijklmno }}$ & $6.3^{\mathrm{ab}}$ & $6.3^{\mathrm{ab}}$ & 37 & 65 & 9.7 \\
\hline 107 & VI002051BG & India & $2.6^{\mathrm{ab}}$ & $7.3^{\mathrm{abcd}}$ & $3.6^{\text {abcdefghijklmno }}$ & $6.1^{\mathrm{abc}}$ & $6.6^{\mathrm{ab}}$ & 40 & 69 & 9.2 \\
\hline 125 & VI002487AG & Pakistan & $1.5^{\mathrm{ab}}$ & $3.1^{\text {abcdef }}$ & $5.3^{\text {abcdefghijklmno }}$ & $6.1^{\mathrm{abc}}$ & $5.9^{\mathrm{ab}}$ & 39 & 70 & 8.2 \\
\hline 127 & VI002529B-BL & Thailand & $1.5^{\mathrm{ab}}$ & $2.3^{\text {bcdef }}$ & $2.9^{\text {bcdefghijklmnop }}$ & $5.1^{\mathrm{abcd}}$ & $1.0^{\mathrm{b}}$ & 40 & 72 & 7.2 \\
\hline 131 & VI002587AG & Australia & $1.5^{\mathrm{ab}}$ & $7.3^{\text {abcde }}$ & $3.9^{\text {abcdefghijklmno }}$ & $5.0^{\mathrm{abcd}}$ & $1.8^{\mathrm{ab}}$ & 37 & 67 & 9.9 \\
\hline 146 & VI002993BG & India & $1.6^{\mathrm{ab}}$ & $4.1^{\text {abcdef }}$ & $4.8^{\text {abcdefghijklmno }}$ & $4.7^{\mathrm{abcd}}$ & $3.9^{\mathrm{ab}}$ & 37 & 66 & 9.9 \\
\hline 148 & VI003019A-BLM & Unknown & $1.5^{\mathrm{ab}}$ & $5.1^{\text {abcdef }}$ & $2.0^{\mathrm{klmnop}}$ & $6.5^{\mathrm{ab}}$ & $5.5^{\mathrm{ab}}$ & 37 & 69 & 7.1 \\
\hline 149 & VI003019BG & Unknown & $1.0^{\mathrm{b}}$ & $3.8^{\text {abcdef }}$ & $4.5^{\text {abcdefghijklmno }}$ & $5.6^{\text {abcd }}$ & $3.0^{\mathrm{ab}}$ & 39 & 70 & 5.4 \\
\hline 154 & VI003068A-BR & India & $2.1^{\mathrm{ab}}$ & $2.2^{\text {bcdef }}$ & $2.6^{\text {bcdefghijklmnop }}$ & $*$ & $*$ & 44 & 74 & 9.0 \\
\hline 155 & VI003070AG & India & $3.0^{\mathrm{ab}}$ & $5.8^{\text {abcdef }}$ & $4.8^{\text {abcdefghijklmno }}$ & $4.7^{\mathrm{abcd}}$ & $1.9^{\mathrm{ab}}$ & 38 & 67 & 8.8 \\
\hline 158 & VI003135B-BL & India & $1.8^{\mathrm{ab}}$ & $3.6^{\text {abcdef }}$ & $5.7^{\text {abcdefghijklmn }}$ & $6.0^{\mathrm{abc}}$ & $2.5^{\mathrm{ab}}$ & 37 & 63 & 7.8 \\
\hline 162 & VI003183AG & India & $4.2^{\mathrm{ab}}$ & $4.5^{\text {abcdef }}$ & $6.3^{\text {abcdefghijklm }}$ & $5.4^{\mathrm{abcd}}$ & $8.8^{\mathrm{a}}$ & 40 & 67 & 7.6 \\
\hline 167 & VI003235AG & India & $1.5^{\mathrm{ab}}$ & $2.9^{\text {bcdef }}$ & $3.0^{\text {bcdefghijklmnop }}$ & $4.7^{\mathrm{abcd}}$ & $3.3^{\mathrm{ab}}$ & 44 & 74 & 10.1 \\
\hline 169 & VI003251A-BL & India & $1.4^{\mathrm{ab}}$ & $4.2^{\text {abcdef }}$ & $2.6^{\text {bcdefghijklmnop }}$ & $6.0^{\mathrm{abc}}$ & $3.9^{\mathrm{ab}}$ & 41 & 72 & 16.1 \\
\hline 170 & VI003251A-BLM & India & $2.1^{\mathrm{ab}}$ & $3.9^{\text {abcdef }}$ & $3.9^{\text {abcdefghijklmno }}$ & $5.7^{\text {abcd }}$ & $3.9^{\mathrm{ab}}$ & 38 & 66 & 9.9 \\
\hline 175 & VI003332AG & India & $2.1^{\mathrm{ab}}$ & $4.8^{\text {abcdef }}$ & $6.7^{\text {abcdefghijkl }}$ & $6.5^{\mathrm{ab}}$ & $8.8^{\mathrm{a}}$ & 42 & 74 & 8.0 \\
\hline 176 & VI003337BR & India & $1.5^{\mathrm{ab}}$ & $2.9^{\text {bcdef }}$ & $2.0^{\mathrm{jklmnop}}$ & $*$ & $*$ & 42 & 75 & 9.4 \\
\hline 180 & VI003407AG & India & $1.8^{\mathrm{ab}}$ & $5.1^{\text {abcdef }}$ & $4.0^{\text {abcdefghijklmno }}$ & $5.9^{\mathrm{abc}}$ & $7.4^{\mathrm{ab}}$ & 39 & 68 & 8.3 \\
\hline
\end{tabular}

(Continued on next page)

\footnotetext{
${ }^{\mathrm{w}}$ Disease severity based on a 1-to-9 rating scale. The accessions showing disease severity scores of 1 were immune (I) and free from disease, accessions having mean disease severity scores ranging from 1.1 to 2.0 were highly resistant (HR), 2.1 to 3.0 were resistant (R), 3.1 to 4.0 were moderately resistant (MR), 4.1 to 5.0 were moderately susceptible (MS), 5.1 to 7.0 were susceptible (S), and 7.1 to 9.0 were highly susceptible (HS).

${ }^{x}$ Disease severity mean of each accession followed by different letters within a column are significantly different accordingly to Tukey's test $(P<0.05)$.

*: Not included in Palampur trial due to lack of multiple resistance against other diseases. \$: Damaged due to heavy rain.

${ }^{\mathrm{y}}$ Significantly not different.

${ }^{\mathrm{z}}$ Less than 60 days: early maturing, 61 to 75 days: intermediate maturing, $>75$ days: late maturing.
} 


\begin{tabular}{|c|c|c|c|c|c|c|c|c|c|c|}
\hline \multirow{3}{*}{$\begin{array}{l}\text { MC } \\
\text { no. }\end{array}$} & \multirow{3}{*}{$\begin{array}{c}\text { Accession } \\
\text { name }\end{array}$} & \multirow[b]{3}{*}{ Origin } & \multicolumn{5}{|c|}{ Mean disease severity scores ${ }^{w}$} & \multicolumn{3}{|c|}{ Agronomic characteristics } \\
\hline & & & \multicolumn{3}{|c|}{ Hyderabad } & \multicolumn{2}{|c|}{ Palampur } & \multirow{2}{*}{$\begin{array}{c}\text { Days to } 50 \% \\
\text { flowering }\end{array}$} & \multirow{2}{*}{$\begin{array}{c}\text { Days to } \\
\text { maturity }^{y, z}\end{array}$} & \multirow{2}{*}{$\begin{array}{l}\text { Yield per } \\
\text { plant }(g)^{y}\end{array}$} \\
\hline & & & 2016 x & $2017^{x}$ & $2018^{x}$ & $2018^{x}$ & $2019^{x}$ & & & \\
\hline 185 & VI003465BG & India & $2.7^{\mathrm{ab}}$ & $2.7^{\text {bcdef }}$ & $6.8^{\text {abcdefghijk }}$ & $5.0^{\mathrm{abcd}}$ & $2.0^{\mathrm{ab}}$ & 40 & 68 & 8.8 \\
\hline 190 & VI003493BG & India & $1.4^{\mathrm{ab}}$ & $2.4^{\text {bcdef }}$ & $1.9^{\text {mnop }}$ & $*$ & $*$ & 37 & 66 & 8.3 \\
\hline 191 & VI003517BG & India & $1.1^{\mathrm{b}}$ & $1.9^{\mathrm{cdef}}$ & $4.0^{\text {abcdefghijklmno }}$ & $4.3^{\mathrm{abcd}}$ & $4.8^{\mathrm{ab}}$ & 38 & 70 & 8.5 \\
\hline 194 & VI003534BG & India & $2.2^{\mathrm{ab}}$ & $1.2^{\mathrm{abcdef}}$ & $2.9^{\text {bcdefghijklmnop }}$ & $5.0^{\mathrm{abcd}}$ & $8.1^{\mathrm{ab}}$ & 42 & 79 & 12.8 \\
\hline 197 & VI003563A-BR & India & $5.0^{\mathrm{ab}}$ & $4.2^{\mathrm{abcdef}}$ & $4.9^{\text {abcdefghijklmno }}$ & $6.4^{\mathrm{ab}}$ & $5.0^{\mathrm{ab}}$ & 37 & 67 & 9.8 \\
\hline 207 & VI003699B-BG & India & $1.0^{\mathrm{b}}$ & $3.0^{\text {abcdef }}$ & $1.0^{\mathrm{p}}$ & $4.0^{\mathrm{abcd}}$ & $1.4^{\mathrm{ab}}$ & 37 & 73 & 19.5 \\
\hline 208 & VI003720BG & India & $2.5^{\mathrm{ab}}$ & $1.9^{\text {cdef }}$ & $2.0^{\mathrm{klmnop}}$ & $4.3^{\mathrm{abcd}}$ & $2.2^{\mathrm{ab}}$ & 38 & 66 & 6.6 \\
\hline 212 & VI003744AG & India & $1.6^{\mathrm{ab}}$ & $5.6^{\text {abcdef }}$ & $2.3^{\text {ghijklmnop }}$ & $5.7^{\mathrm{abcd}}$ & $2.5^{\mathrm{ab}}$ & 38 & 68 & 9.5 \\
\hline 214 & VI003760BG & India & $1.4^{\mathrm{ab}}$ & $2.4^{\text {bcdef }}$ & $2.5^{\text {defghijklmnop }}$ & $*$ & $*$ & 37 & 70 & 7.0 \\
\hline 215 & VI003785BG & India & $2.2^{\mathrm{ab}}$ & $3.5^{\text {abcdef }}$ & $7.0^{\text {abcdefghijklmno }}$ & $5.3^{\mathrm{abcd}}$ & $\$$ & 37 & 65 & 11.0 \\
\hline 222 & VI003894B-BLM & India & $6.5^{\mathrm{ab}}$ & $2.7^{\text {bcdef }}$ & $2.0^{\mathrm{klmnop}}$ & $3.6^{\mathrm{bcd}}$ & $1.9^{\mathrm{ab}}$ & 41 & 66 & 7.8 \\
\hline 235 & VI003958B-BLM & India & $1.5^{\mathrm{ab}}$ & $3.2^{\text {abcdef }}$ & $3.1^{\text {bcdefghijklmnop }}$ & $*$ & $*$ & 39 & 69 & 7.6 \\
\hline 236 & VI003959BG & India & $2.7^{\mathrm{ab}}$ & $2.1^{\text {bcdef }}$ & $3.9^{\text {abcdefghijklmno }}$ & $2.6^{\mathrm{bcd}}$ & $2.5^{\mathrm{ab}}$ & 39 & 71 & 12.5 \\
\hline 239 & VI004024AG & Australia & $1.5^{\mathrm{ab}}$ & $5.7^{\text {abcdef }}$ & $3.5^{\text {abcdefghijklmnop }}$ & $4.0^{\mathrm{abcd}}$ & $3.0^{\mathrm{ab}}$ & 39 & 73 & 10.1 \\
\hline 241 & VI004045A-DGM & India & $1.9^{\mathrm{ab}}$ & $2.8^{\text {bcdef }}$ & $2.6^{\text {bcdefghijklmnop }}$ & $*$ & $*$ & 40 & 71 & 9.8 \\
\hline 251 & VI004244B-BR & India & $7.9^{\mathrm{ab}}$ & $8.0^{\mathrm{ab}}$ & $6.4^{\text {abcdefghijklm }}$ & $6.1^{\mathrm{abc}}$ & $7.5^{\mathrm{ab}}$ & 36 & 62 & 5.0 \\
\hline 258 & VI004423AG & Iran & $7.5^{\mathrm{ab}}$ & $7.6^{\mathrm{abc}}$ & $5.3^{\text {abcdefghijklmno }}$ & $6.0^{\mathrm{abcd}}$ & $9.0^{\mathrm{a}}$ & 37 & 64 & 5.0 \\
\hline 267 & VI004743AG & India & $2.2^{\mathrm{ab}}$ & $1.6^{\mathrm{def}}$ & $3.0^{\text {bedefghijklmnop }}$ & $5.0^{\mathrm{abcd}}$ & $3.4^{\mathrm{ab}}$ & 40 & 73 & 11.9 \\
\hline 270 & VI004811BG & India & $2.6^{\mathrm{ab}}$ & $5.6^{\text {abcdef }}$ & $4.4^{\text {abcdefghijklmno }}$ & $6.3^{\mathrm{ab}}$ & $8.0^{\mathrm{ab}}$ & 37 & 67 & 8.0 \\
\hline 271 & VI004822BG & India & $3.4^{\mathrm{ab}}$ & $2.7^{\text {bcdef }}$ & $4.4^{\text {abcdefghijklmno }}$ & $6.0^{\mathrm{abc}}$ & $4.9^{\mathrm{ab}}$ & 36 & 66 & 7.1 \\
\hline 292 & VI005024B-BL & Taiwan & $1.4^{\mathrm{ab}}$ & $2.0^{\text {cdef }}$ & $2.0^{\mathrm{ijklmnop}}$ & $4.6^{\mathrm{abcd}}$ & $3.0^{\mathrm{ab}}$ & 42 & 76 & 10.3 \\
\hline 293 & VI005030BY & Mexico & $7.1^{\mathrm{ab}}$ & $2.7^{\text {bcdef }}$ & $2.6^{\text {bcdefghijklmnop }}$ & $5.3^{\mathrm{abcd}}$ & $3.5^{\mathrm{ab}}$ & 42 & 71 & 6.9 \\
\hline 294 & VI005041AG & Unknown & $2.6^{\mathrm{ab}}$ & $6.9^{\text {abcde }}$ & $6.0^{\text {abcdefghijklm }}$ & $6.0^{\mathrm{abc}}$ & $\$$ & 37 & 66 & 10.9 \\
\hline
\end{tabular}

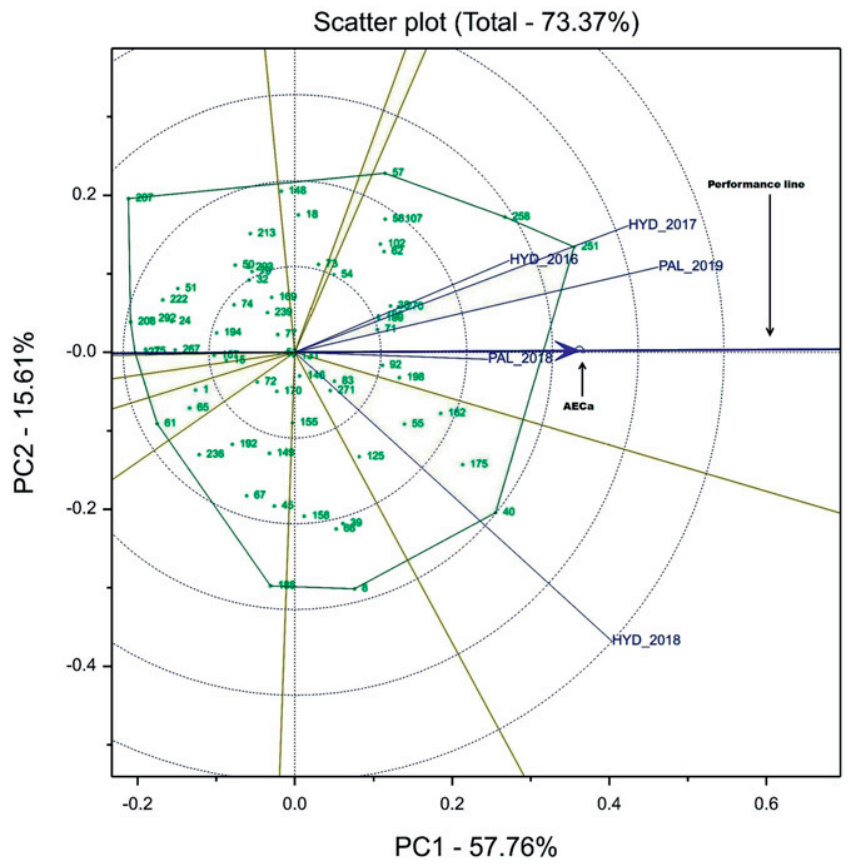

Fig. 3. GGE biplot of first and second principal components (PC1 and PC2, respectively) based on anthracnose disease severity scores of 65 mungbean mini-core accessions in five environments in India. HYD: Hyderabad, PAL: Palampur, AECa: abscissa of the "average environment coordination" axis, which connects the origin with the environmental average (refer to Table 1 for the names of the accessions and environments).

as on AECa (Fig. 3), and the angles were $<90^{\circ}$, demonstrating the high correlations among them. However, with Hyd_2018, some of the correlations were only moderate. The respective higher and lower PC1 and PC2 scores of environments Hyd_2016, Hyd_2017, Hyd_2018, PAL_2018, and PAL_2019 indicated the better discriminating ability of test environments. A close association was observed between Hyd_2017 and Hyd_2016. Over the years, all test environments formed acute angles thus indicating concurrence about genotypic response toward anthracnose disease severity.
In addition, a pooled analysis of variance (Table 3 ) of the test accessions common in all five environments for anthracnose severity revealed that all three sources of variations were highly significant $(P<0.0001)$; with a higher portion of variation because of $\mathrm{G} \times \mathrm{E}$ (40.38\%) followed by E (39.31\%) and G (20.31\%).

\section{Discussion}

In South Asia and Southeast Asia, mungbean anthracnose occurs during the summer rainy season resulting in severe symptoms and yield loss. The pathogen $C$. truncatum is a hemibiotroph that survives as mycelium in the infected crop residue or seeds (Manandhar and Hartman 1999). The pathogen infects many crops, which makes disease management in mungbean difficult. Investigations have been carried out to identify resistance sources against multiple diseases from mini-core collections of chickpea (Pande et al. 2006), sorghum (Sharma et al. 2010), and pigeon pea (Sharma et al. 2012b; Upadhyaya et al. 2006), but such efforts have not been undertaken in short-duration mungbean. Therefore, the present study was proposed to identify resistance sources to anthracnose from 296 mungbean mini-core collections. Three-year screening of 296 accessions during kharif (rainy) season in Hyderabad and a subset of 74 selected accessions for two years in Palampur led to the identification of seven accessions, MC-24, MC-51, MC-75, MC-127, MC-207, MC-208, and MC-292, with stable anthracnose resistance at both test locations. In 2019 in Palampur, nine accessions were damaged due to heavy rains even after the gap-filling; therefore, only 65 accessions were scored for disease severity. Statistical analysis of each year's data revealed large and significant variations in the degree of disease severity among the 65 mungbean accessions common at both locations and in all the environments. Out of the 65 accessions, only seven showed anthracnose resistance at both locations. In addition, the pathogen causing anthracnose in each year's research plot at both Hyderabad and Palampur was identical and was identified as C. truncatum based on cultural, morphological, and molecular characterizations. However, the $C$. truncatum isolates in each year trial showed a variation in culture and morphological characteristics, as the variable range of growth pattern and conidial size were reported based on the microscopic studies and morpho-cultural characteristics. The conidial size of each isolate of the pathogen observed in the present study was within the range of conidial size of $C$. truncatum reported by earlier investigators (Jagtap and Sontakke 2009; Rogério et al. 
2017). It confirmed that the pathogen infecting mungbean in each year's research plot at both locations was $C$. truncatum.

In Hyderabad, the accessions MC-70 (VI001471AG), MC-203 (VI003658BG), MC-22 (VI000551AG), and MC-50 were R in 2016 and 2018, while these were MS in 2017. Accessions MC-7 (VI000188 A-BLM) and MC-222 were R in 2017 and 2018 and S in 2016. Additionally, in 2016 more accessions were disease-free, and the numbers decreased progressively in 2017 and 2018. It showed that anthracnose severity was more in 2017 and 2018 than in 2016. In Palampur, only two accessions showed resistance in 2018, whereas in 2019, the numbers of $\mathrm{R}$ and $\mathrm{S}$ accessions increased. The differential reaction of mungbean accessions in the environments may be attributed to variability in the virulence among the pathogen population (Marley et al. 2001; Sharma et al. 2019). The variability in the genetics and virulence in the fungal isolates and their subsequent varied responses under diverse geographical locations may account for the varying severity of anthracnose across years and locations (Kulkarni and Chopra 1982). It could also be due to the prevailing climatic conditions during the experimental periods and disease development period.

In 2016, the RH was higher in Hyderabad, followed by 2017 and 2018, and the total rainfall in $2016(989.79 \mathrm{~mm})$ was higher than in 2017 or 2018. However, the temperature did not vary much during the period of study (Table 4). In Palampur, RH and rainfall were higher in 2018 than in 2019, but the temperature did not vary significantly during the period under investigation. Therefore, it is evident that differences in $\mathrm{RH}$ and rainfall under the period of study could explain the higher disease pressure in 2017 and 2018 than in 2016 in Hyderabad, and in 2019 than in 2018 in Palampur. Palampur results differed between the years, which may be due to the differences in weather parameters, particularly rainfall and RH (Table 4). In the present study, the accessions such as MC-40, MC-251, and MC-258 showed consistently higher mean disease severity scores $(>6.0$ and $<9.0$ on 1-to-9 point scale) at both the locations, indicating adequate disease pressure under natural conditions. These accessions may be used as susceptible checks in anthracnose disease screening trials in the future.

The GGE biplot analysis has been widely used in breeding programs for the selection of accessions with durable stability and low disease pressure; for instance, Cercospora leaf spot of mungbean (Das et al. 2020), soybean rust (Twizeyimana et al. 2008), and chickpea Fusarium wilt (Sharma et al. 2012a; Sharma et al. 2019). In the present study, multienvironment evaluation of 65 accessions at the five test environments has shown significant differences $(P<$ $0.0001)$ in $\mathrm{E}, \mathrm{G}$, and $\mathrm{G} \times \mathrm{E}$ interaction for anthracnose resistance. In addition, the highly significant $(P<0.0001)$ effect of genotype and environment on the disease severity indicated the varied performance of accessions across years and locations. The existence of $\mathrm{G} \times \mathrm{E}$ interaction might have resulted in a low resistance, particularly among the resistant varieties grown in environments with high disease pressure. In this study, the variance of $\mathrm{G} \times \mathrm{E}$ interactions was more than the genotype variance, signifying that disease severity was affected by both $\mathrm{G}$ and $\mathrm{E}$. Further, in the GGE biplot of 65 accessions, the resistant accessions (MC-24, MC-51, MC-75, MC-127, MC-208, MC-207, and MC-292) were placed farthest toward the left side, indicating the lower disease severity scores for anthracnose across years and locations. These accessions may be used as donors to develop anthracnose-resistant prebreeding materials for utilization in mungbean breeding programs, which aim to develop anthracnoseresistant varieties or genotypes with desirable agronomic traits to be directly released as varieties. The resistant accessions could be used to develop a biparental population for further QTL analysis.
In the breeding programs, multienvironment evaluation of accessions helps in the selection of stable and resistant accessions. The future selection of resistant accessions based on multienvironment and multiyear screening may be used as a model, and the identified accessions could be used as the prime resistance donors in the resistance breeding programs for a specific adaptation for a particular climatic zone and also the identification of key susceptible lines for use as positive infection control in future experiments. The varying response of some accessions at Hyderabad and Palampur reflected the influence of environments toward variability of anthracnose severity. Further, it is evident that resistance to biotic stresses, such as anthracnose resistance of mungbean, may be identified among the mini-core collection, comprising only $2 \%$ of the total available germplasm. This study identified stable anthracnose-resistant mungbean accessions for future resistance breeding programs. From the mungbean mini-core collection, identification of the accessions having disease resistance would permit the use of varied resistance sources for breeding programs in the future and will ensure better probabilities of success in the improvement of mungbean. Besides that, the 296 mungbean mini-cores could be used for a GWAS study.

As has been observed in the present study, few attempts were made to identify anthracnose resistance in mungbean. For example, accessions ML 1486, 1464, 1194, and 1349 have been reported as anthracnose-resistant (Kaur et al. 2011). It implies that only limited sources of anthracnose resistance have been reported and the present study focused on searching for new sources that could be used in the breeding programs. Even though anthracnose resistance breeding has been in progress for the last two decades, little success has been achieved in $C$. truncatum, mostly due to the absence of resistant sources and high complexity of the causal pathogen (Chongo and Bernier 1999). The inheritance of resistance to $C$. truncatum in chili has been studied (Kim et al. 2008; Pakdeevaraporn et al. 2005); however, such studies have not been undertaken for anthracnose of mungbean. It would be relevant to study the genetics of resistance in the identified anthracnose-resistant accessions for their resistance mechanisms. As far as genetic resistance is concerned, the genetics of anthracnose resistance has been studied in other crops. For instance, few QTLs have been reported against $C$. truncatum in chili (Mahasuk et al. 2016), lentil (Tullu et al. 2006, 2008), and brown blotch in cowpea (Ohlson et al. 2018). However, no such reports are available for anthracnose in mungbean. Therefore, the $C$. truncatum resistant accessions identified in the present investigation could be exploited for developing mapping populations toward detection of resistant responsive QTLs in the C. truncatum background. In addition, for enabling the marker-assisted selection, mapping populations' development from the resistant sources would be needed for gene mapping.

Table 4. Average weekly temperature, average weekly relative humidity, and total rainfall during the experimental period July to September at test locations

\begin{tabular}{|c|c|c|c|c|}
\hline \multirow{2}{*}{$\begin{array}{l}\text { Year (July to } \\
\text { September) }\end{array}$} & \multicolumn{2}{|c|}{ Temperature $\left({ }^{\circ} \mathbf{C}\right)$} & \multirow{2}{*}{$\begin{array}{c}\text { Rainfall } \\
(\mathbf{m m})\end{array}$} & \multirow{2}{*}{$\begin{array}{c}\text { Relative } \\
\text { humidity }(\%)\end{array}$} \\
\hline & Max & Min & & \\
\hline \multicolumn{5}{|l|}{ Hyderabad } \\
\hline 2016 & 30.05 & 22.6 & 989.79 & 68.1 \\
\hline 2017 & 30.96 & 22.6 & 826.68 & 65.9 \\
\hline 2018 & 31.34 & 22.6 & 441.07 & 60.66 \\
\hline \multicolumn{5}{|l|}{ Palampur } \\
\hline 2018 & 27.6 & 19.2 & $2,132.2$ & 80.3 \\
\hline 2019 & 28.5 & 19.2 & $1,366.8$ & 75.6 \\
\hline
\end{tabular}

Table 3. Combined analysis of variance for anthracnose severity in 65 mungbean mini-core accessions common in multiyear evaluation trials in Hyderabad and Palampur, India

\begin{tabular}{|c|c|c|c|c|c|}
\hline Random term & Component & Standard error (SE) & Chisq & Prob $>$ Chisq & $\%$ Contribution \\
\hline Environment (E) & 0.06597 & 0.04955 & 12.00 & 0.0005 & 39.31 \\
\hline Genotype (G) & 0.03409 & 0.01000 & 27.10 & $<0.0001$ & 20.31 \\
\hline Genotype $\times$ environment $(\mathrm{G} \times \mathrm{E})$ & 0.06777 & 0.01186 & 64.80 & $<0.0001$ & 40.38 \\
\hline
\end{tabular}


Based on ITS sequence BLAST analysis, the present study identified $C$. truncatum as a causal agent of mungbean anthracnose in Hyderabad and Palampur, India. Screening of mini-core accessions in multiple years at two locations revealed that MC-24, MC-51, MC-75, MC-127, MC-208, MC-207, and MC-292 accessions were resistant in Hyderabad and Palampur, India. Therefore, in the areas where anthracnose is the prevalent problem and $C$. truncatum is the dominant causal agent, cultivation of these accessions could be suggested. The host-plant resistance is an eco-friendly and cost-effective management strategy. Therefore, the resistant accessions identified in the present study through multilocation and multiyear evaluations could also be harnessed in breeding programs as resistance donors for developing anthracnose-resistant varieties.

\section{Literature Cited}

Abang, M. M., Winter, S., Green, K. R., Hoffmann, P., Mignouna, H. D., and Wolf, G. A. 2002. Molecular identification of Colletotrichum gloeosporioides causing yam anthracnose in Nigeria. Plant Pathol. 51:63-71.

Bigirimana, J., and Höfte, M. 2001. Bean anthracnose: inoculation methods and influence of plant stage on resistance of Phaseolus vulgaris cultivars. J. Phytopathol. 149:403-408

Buchwaldt, L., Shaikh, R., Adam, J., Tullu, A., and Slinkard, A. E. 2013. Recessive and dominant genes confer resistance to Colletotrichum truncatum in cultivated lentil. Can. J. Plant Pathol. 35:222-231.

Chaudhari, K. A., and Goel, N. M. 2016. Management of anthracnose disease of mungbean through new fungicidal formulations. J. Pure Appl. Microbiol. 10:691-696.

Chongo, G., and Bernier, C. C. 1999. Field and growth chamber evaluation of components of partial resistance to Colletotrichum truncatum in lentil. Can. J. Plant Pathol. 21:58-63.

Damm, U., Sato, T., Alizadeh, A., Groenewald, J. Z., and Crous, P. W. 2019. The Colletotrichum dracaenophilum, C. magnum and C. orchidearum species complexes. Stud. Mycol. 92:1-46.

Das, A., Gupta, S., Parihar, A. K., Singh, A., Chand, R., Pratap, A., Singha, K. D., and Kushwaha, K. P. S. 2020. Delineating genotype $\times$ environment interactions towards durable resistance in mungbean against Cercospora leaf spot (Cercospora canescens) using GGE biplot. Plant Breed. 139:639-650.

Deeksha, J., and Tripathi, H. S. 2002. Cultural, biological and chemical control of anthracnose of urdbean. J. Mycol. Pl. Path. 32:52-55.

Diao, Y. Z., Zhang, C., Lin, D., and Liu, X. L. 2014. First report of Colletotrichum truncatum causing anthracnose of tomato in China. Plant Dis. 98:687.

Frankel, O. H. 1984. Genetic perspective of germplasm conservation. Pages 161-170 in: Genetic manipulations: Impact on man and society. W. Arber, K. Limensee, W. J. Peacock, and P. Stralinger, eds. Cambridge Univ. Press, Cambridge, UK.

Freeman, S., Shabi, E., and Katan, T. 2000. Characterization of Colletotrichum acutatum causing anthracnose of anemone (Anemone coronaria L.). Appl. Environ. Microbiol. 66:5267-5272.

Goswami, S., Thind, T. S., and Nagrale, D. T. 2013. Efficacy of new fungicides against anthracnose of chili (Capsicum annuum) caused by Colletotrichum capsici. Indian Phytopathol. 66:207-208.

He, Y., Chen, Q., Shu, C., Yang, M., and Zhou, E. 2016. Colletotrichum truncatum, a new cause of anthracnose on Chinese flowering cabbage (Brassica parachinensis) in China. Trop. Plant Pathol. 41:183-192.

Jagtap, G. P., and Sontakke, P. L. 2009. Taxonomy and morphology of Colletotrichum truncatum isolates pathogenic to soybean. Afr. J. Agric. Res. 4:1483-1487.

Kaur, L., Singh, P., and Sirari, A. 2011. Biplot analysis for locating multiple disease resistant diversity in mungbean germplasm. Dis. Res. 26:55-60.

Khan, A. A., Khan, R. U., and Singh, R. 2005. Management of Cercospora leaf spot and anthracnose diseases of mungbean by fungicides. Ann. Plant Prot. Sci. 13:465-529

Kim, S. H., Yoon, J. B., Do, J. W., and Park, H. G. 2008. A major recessive gene associated with anthracnose resistance to Colletotrichum capsici in chili pepper (Capsicum annuum L.). Breed. Sci. 58:137-141.

Kulkarni, R. N., and Chopra, V. L. 1982. Environment as the cause of differential interaction between host cultivars and pathogenic races. Phytopathology 72:1384-1386

Kulkarni, S. A. 2009. Epidemiology and integrated management of anthracnose of green gram. M.Sc. (Agri.) Thesis submitted to UAS Dharwad, Karnataka, India.

Mahasuk, P., Struss, D., and Mongkolporn, O. 2016. QTLs for resistance to anthracnose identified in two Capsicum sources. Mol. Breed. 36:10.

Manandhar, J. B., and Hartman, G. L. 1999. Anthracnose. Pages 13-14 in: Compendium of Soybean Diseases, 4th Ed., G. L. Hartman, J. B. Sinclair, and J. C. Rupe, eds. APS Press, St. Paul, MN.

Mandal, R., Narendra, S., Mehta, S. K., and Khirbat, S. K. 2015. Influence of environmental conditions on the incidence of anthracnose of mungbean. Ann. Agri Bio Res. 20:184-187.
Marak, T., Umbrey, Y., Mahapatra, S., and Das, S. 2019. Cultural, morphological and bio-chemical variability of different isolates of Colletotrichum truncatum causing anthracnose of greengram. Arch. Phytopath. Plant Prot. 52:141-154.

Marley, P. S., Thakur, R. P., and Ajay, I. O. 2001. Variation among foliar isolates of Colletotrichum sublineolum of sorghum in Nigeria. Field Crops Res. 69:133-142.

Mbeyagala, K. E., Amayo, R., Obuo, J. P., Pandey, A. K., War, A. R., and Nair, R. M. 2017. A manual for mungbean (greengram) production in Uganda. National Agricultural Research Organization (NARO), Entebbe, Uganda.

Miller-Butler, M. A., Smith, B. J., Babiker, E. M., Kreiser, B. R., and Blythe E. K. 2018. Comparison of whole plant and detached leaf screening techniques for identifying anthracnose resistance in strawberry plants. Plant Dis. 102:2112-2119.

Möller, E. M., Bahnweg, G., Sandermann, H., and Geiger, H. H. 1992. A simple and efficient protocol for isolation of high molecular weight DNA from filamentous fungi, fruit bodies, and infected plant tissues. Nucleic Acids Res. 20:6115-6116.

Nair, R. M., Pandey, A. K., War, A. R., Hanumantharao, B., Shwe, T., Alam A. K. M. M., Pratap, A., Malik, S. R., Karimi, R., Mbeyagala, E. K., Douglas, C. A., Rane, J., and Schafleitner, R. 2019. Biotic and abiotic constraints in mungbean production-progress in genetic improvement. Front Plant Sci. 10:1340.

Noble, T., Young, A., Douglas, C., Williams, B., and Mundree, S. 2019. Diagnosis and management of halo blight in Australian mungbeans: a review. Crop Pasture Sci. 70:195-203.

Ohlson, E. W., Thio, G. I., Sawadogo, M., Sérémé, P., and Timko, M. P. 2018 Quantitative trait loci analysis of brown blotch resistance in cowpea variety KN1. Mol. Breed. 38:110.

Oo, M. M., and Oh, S.-K. 2020. First report of anthracnose of chili pepper fruit caused by Colletotrichum truncatum in Korea. Plant Dis. 104:564.

Pakdeevaraporn, P., Wasee, S., Taylor, P. W. J., and Mongkolporn, O. 2005. Inheritance of resistance to anthracnose caused by Colletotrichum capsici in Capsicum. Plant Breed. 124:206-208.

Pande, S., Kishore, G. K., Upadhayaya, H. D., and Rao, J. N. 2006. Identification of sources of multiple disease resistance in mini- core collection of chickpea. Plant Dis. 90:1214-1218.

Poti, T., Mahawan, K., Cheewangkoon, R., Arunothayanan, H., Akimitsu, K., and Nalumpang, S. 2020. Detection and molecular characterization of carbendazim-resistant Colletotrichum truncatum isolates causing anthracnose of soybean in Thailand. J. Phytopathol. 168:267-278.

Pratap, A., Douglas, C., Prajapati, U., Kumari, G., War, A. R., Tomar, R. Tomar, R., Pandey, A. K., and Dubey, S. 2020. Breeding progress and future challenges: Biotic stresses. Pages 55-88 in: The Mungbean Genome. Compendium of Plant Genomes. R. Nair, R. Schafleitner, and S. H. Lee, eds. Springer, Cham, Switzerland.

Rani, A., Donovan, N., and Mantri, N. 2019. Review: The future of plant pathogen diagnostics in a nursery production system. Biosens. Bioelectron. 145:111631.

Rogério, F., Ciampi-Guillardi, M., Barbieri, M. C. G., Bragança, C. A. D. Seixas, C. D. S., Almeida, A. M. R., and Massola, N. S. 2017. Phylogeny and variability of Colletotrichum truncatum associated with soybean anthracnose in Brazil. J. Appl. Microbiol. 122:402-415.

Rogério, F., Gladieux, P., Massola, N. S., and Ciampi-Guillardi, M. 2019. Multiple introductions without admixture of Colletotrichum truncatum associated with soybean anthracnose in Brazil. Phytopathology 109:681-689.

Saha, P., and Mohanty, T. R. 2017. Management module of foliar diseases of Urdbean at Keonjhar, Odisha. Ann. Plant Prot. Sci. 25:334-337.

Sain, S. K., and Pandey, A. K. 2018. Evaluation of some Trichoderma harzianum isolates for the management of soilborne diseases of Brinjal and Okra. Proc. Natl. Acad. Sci., India, Sect. B Biol. Sci. 88:905-914.

SAS Institute. 2018. SAS/STAT® 15.1 User's Guide. SAS Institute Inc., Cary, NC.

Schafleitner, R., Nair, R. M., Rathore, A., Wang, Y., Lin, C., Chu, S., Lin, P., Chang, J., and Ebert, A. W. 2015. The AVRDC-The World Vegetable Center mungbean (Vigna radiata) core and mini core collections. BMC Genomics $16: 344$

Sharma, M., Ghosh, R., Tarafdar, A., Rathore, A., Chobe, D. R., Kumar, A. V., Gaur, P. M., Samineni, S., Gupta, O., Singh, N. P., Saxena, D. R., Saifulla M., Pithia, M. S., Ghante, P. H., Mahalinga, D. M., Upadhyay, J. B., and Harer, P. N. 2019. Exploring the genetic cipher of chickpea (Cicer arietinum L.) through identification and multi-environment validation of resistant sources against fusarium wilt (Fusarium oxysporum f. sp. ciceris). Front. Sustain. Food Syst. 3:78

Sharma, M., Kiran Babu, T., Gaur, P. M., Ghosh, R., Rameshwar, T., Chaudhary, R. G., et al. 2012a. Identification and multi-environment validation of resistance to Fusarium oxysporum f. sp. ciceris in chickpea. Field Crops Res. 135:82-88

Sharma, M., Rathore, A., Mangala, U. N., Ghosh, R., Sharma, S., Upadhayay, H. D., and Pandey, S. 2012b. New sources of resistance to Fusarium wilt and sterility mosaic disease in a mini-core collection of pigeonpea germplasm. Eur. J. Plant Pathol. 133:707-714.

Sharma, P. N., Kaur, M., Sharma, O. P., Sharma, P., and Pathania, A. 2005 Morphological, pathological and molecular variability in Colletotrichum 
capsici, the cause of fruit rot of chillies in the subtropical region of northwestern India. J. Phytopathol. 153:232-237.

Sharma, R., Rao, V. P., Upadhyaya, H. D., Reddy, V. G., and Thakur, R. P. 2010. Resistance to grain mold and downy mildew in a mini-core collection of sorghum germplasm. Plant Dis. 94:439-444.

Sharma, S. K., Gupta, G. K., and Ramteke, R. 2011. Colletotrichum truncatum [(Schw.) Andrus \& W.D. Moore], the causal agent of anthracnose of soybean (Glycine $\max ($ L.) Merrill) - A Review. Soybean Res. 9:31-52.

Shukla, V., Baghel, S., Maravi, K., Singh, S. K., and Deva, N. 2014. Yield loss assessment in mungbean [Vigna radiata (L.) Wilczek] caused by anthracnose [Colletotrichum truncatum (Schw.) Andrus and Moore] Bioscan 9:1233-1235.

Torres-Calzada, C., Tapia-Tussell, R., Higuera-Ciapara, I., Martin-Mex, R., Nexticapan-Garcez, A., and Perez-Brito, D. 2015. Sensitivity of Colletotrichum truncatum to four fungicides and characterization of thiabendazoleresistant isolates. Plant Dis. 99:1590-1595.

Tullu, A., Tar'an, B., Breitkreutz, C., Banniza, S., Warkentin, T. D., Vandenberg, A., and Buchwaldt, L. 2006. A quantitative-trait locus for resistance to Ascochyta blight [Ascochyta lentis] maps close to a gene for resistance to anthracnose [Colletotrichum truncatum] in lentil. Can. J. Plant Pathol. 28:588-595.

Tullu, A., Taran, B., Warkentin, T., and Wandenberg, A. 2008. Construction of an intraspecific linkage map and QTL analysis for earliness and plant height in lentil. Crop Sci. 48:2254-2264.

Twizeyimana, M., Ojiambo, P., Ikotun, T., Ladipo, J. L., Hartman, G. L., and Bandyopadhyay, R. 2008. Evaluation of soybean germplasm for resistance to soybean rust (Phakopsora pachyrhizi) in Nigeria. Plant Dis. 92:947-952.

Udomkun, P., Tirawattanawanich, C., Ilukor, J., Sridonpai, P., Njukwe, E., Nimbona, P., and Vanlauwe, B. 2019. Promoting the use of locally produced crops in making cereal-legume-based composite flours: An assessment of nutrient, antinutrient, mineral molar ratios, and aflatoxin content. Food Chem. 286:651-658.

Upadhyaya, H. D., Reddy, L. J., Gowda, C. L. L., Reddy, K. N., and Singh, S. 2006. Development of a mini-core subset for enhanced and diversified utilization of pigeonpea germplasm resources. Crop Sci. 46:2127-2132.

VSN International. 2019. Genstat for Windows $20^{\text {th }}$ Edition. VSN International, Hemel Hempstead, UK

White, T. J., Bruns, T., Lee, S., and Taylor, J. 1990. Amplification and direct sequencing of fungal ribosomal RNA genes for phylogenetics. Pages 315-322 in: PCR Protocols. A guide to methods and applications. M. A. Innis, D. H Gelfand, J. J. Sninsky, and T. J. White, eds. Academic Press, San Diego, CA.

Yan, W., Hunt, L. A., Sheng, Q. L., and Szlavnics, Z. 2000. Cultivar evaluation and mega-environment investigation based on the GGE biplot. Crop Sci. 40:597-605.

Yan, W., and Kang, M. S. 2002. GGE Biplot analysis: A Graphical Tool for Breeders, Geneticists, and Agronomists. CRC Press, New York.,

Yang, R., Crossa, J., Cornelius, P. L., and Burgueño, J. 2009. Biplot analysis of genotype $\times$ environment interaction: proceed with caution. Crop Sci. 49:1564-1576. 